\title{
LC-MS and GC-MS Based Isotopic Abundance Ratio Analysis of Consciousness Energy Healing Treated Ofloxacin
}

ISSN: 2637-8078

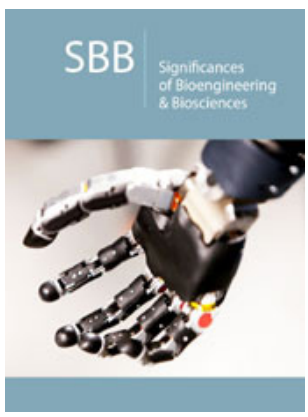

*Corresponding author: Alice Branton, Trivedi Global Inc., USA

Snehasis Jana, Trivedi Science Research Laboratory Pvt. Ltd., Thane (W), Maharashtra, India

Submission: 佂 November 09, 2020 Published: 㘹 December 15, 2020

Volume 4 - Issue 3

How to cite this article: Alice Branton Mahendra Kumar Trivedi, Dahryn Trivedi, Snehasis Jana. LC-MS and GC-MS Based Isotopic Abundance Ratio Analysis of Consciousness Energy Healing Treated Ofloxacin. Significances Bioeng Biosci. 4(3). SBB. 000586. 2020.

DOI: 10.31031/SBB.2020.04.000586

Copyright@ Alice Branton, This article is distributed under the terms of the Creative Commons Attribution 4.0 International License, which permits unrestricted use and redistribution provided that the original author and source are credited.

\author{
Alice Branton ${ }^{1 *}$, Mahendra Kumar Trivedi' ${ }^{1}$, Dahryn Trivedi $^{1}$ and Snehasis \\ Jana $^{2 *}$ \\ ${ }^{1}$ Trivedi Global Inc., USA \\ ${ }^{2}$ Trivedi Science Research Laboratory Pvt Ltd., India
}

\begin{abstract}
Ofloxacin is a broad-spectrum antibiotic, which is useful for the treatment of many Gram-positive and Gram-negative bacterial infections. This study was designed to investigate the impact of The Trivedi Effect ${ }^{\circledR}$-Biofield Energy Healing Treatment on the structural properties and the isotopic abundance ratio of ofloxacin using LC-MS and GC-MS spectroscopy. Ofloxacin sample was divided into two parts, one part of ofloxacin was considered as control (no Biofield Energy Treatment was provided), while the second part was treated with The Trivedi Effect ${ }^{\circledR}$-Consciousness Energy Healing Treatment remotely by a renowned Biofield Energy Healer, Alice Branton and termed as a treated sample. The LC-ESI-MS spectra of both the samples of ofloxacin at the retention time 3.02 minutes exhibited the mass of the protonated molecular ion peak at $\mathrm{m} / \mathrm{z} 362.17[\mathrm{M}+\mathrm{H}]^{+}$(calculated for $\mathrm{C}_{18} \mathrm{H}_{21} \mathrm{FN}_{3} \mathrm{O}_{4}{ }^{+}, 362.15$ ). The LC-MS based isotopic abundance ratio of $\mathrm{P}_{\mathrm{M}+1} / \mathrm{P}_{\mathrm{M}}$ in the treated ofloxacin was significantly increased by $28.65 \%$ compared with the control sample. Thus, ${ }^{13} \mathrm{C},{ }^{2} \mathrm{H},{ }^{15} \mathrm{~N}$, and ${ }^{17} \mathrm{O}$ contributions from $\left(\mathrm{C}_{18} \mathrm{H}_{21} \mathrm{FN}_{3} \mathrm{O}_{4}\right)^{+}$to $\mathrm{m} / \mathrm{z}$ 363.17 in the treated sample were significantly increased compared with the control sample. In the GCMS the retention times of the treated sample (23.08 minute) was found to be close to those of the control sample (22.87 minutes). The peak area \% of treated ofloxacin was increased by $0.7 \%$ compared to the control sample. Similarly, the GC-MS based isotopic abundance ratio of $\mathrm{P}_{\mathrm{M}+1} / \mathrm{P}_{\mathrm{M}}$ in the treated ofloxacin was increased by $3.73 \%$ compared with the control sample. Hence, $,{ }^{13} \mathrm{C},{ }^{2} \mathrm{H},{ }^{15} \mathrm{~N}$, and ${ }^{17} \mathrm{O}$ contributions from $\left(\mathrm{C}_{18} \mathrm{H}_{21} \mathrm{FN}_{3} \mathrm{O}_{4}\right)^{+}$to $\mathrm{m} / \mathrm{z} 318$ in the treated sample were significantly increased compared with the control sample. On the contrary, the isotopic abundance ratio of $\mathrm{P}_{\mathrm{M}+2} / \mathrm{P}_{\mathrm{M}}$ in the treated ofloxacin was decreased by $10.60 \%$ compared with the control sample. Therefore, ${ }^{18} \mathrm{O}$ contributions from $\left(\mathrm{C}_{18} \mathrm{H}_{21} \mathrm{FN}_{3} \mathrm{O}_{4}\right)^{+}$to $\mathrm{m} / \mathrm{z} 319$ in the treated sample were significantly decreased compared with the control sample. The LC-MS and GC-MS based isotopic abundance ratios of $\mathrm{P}_{\mathrm{M}+1} / \mathrm{P}_{\mathrm{M}}\left({ }^{2} \mathrm{H} /{ }^{1} \mathrm{H}\right.$ or ${ }^{13} \mathrm{C} /{ }^{12} \mathrm{C}$ or ${ }^{15} \mathrm{~N} /{ }^{14} \mathrm{~N}$ or $\left.{ }^{17} \mathrm{O} /{ }^{16} \mathrm{O}\right)$ and $\mathrm{P}_{\mathrm{M}+2} / \mathrm{P}_{\mathrm{M}}$ $\left({ }^{18} \mathrm{O} /{ }^{16} \mathrm{O}\right)$ and peak area $\%$ in the treated ofloxacin were significantly altered compared to the control sample. The new form of treated ofloxacin would be better soluble and bioavailable compared to the control sample and would be very useful to design better pharmaceutical formulations that might offer better therapeutic response against urinary tract infections, infectious diarrhoea, infections of the urethra and cervix, pneumonia, cellulitis, chronic bronchitis, tuberculosis, prostatitis, plague, other bacterial infections, etc.
\end{abstract}

Keywords: Ofloxacin; The Trivedi effect ${ }^{\circledR}$; Biofield energy; Consciousness energy healing treatment; LCMS; GC-MS

\section{Introduction}

Ofloxacin is classified under the broad-spectrum antibiotic, which is useful for the treatment of many Gram-positive and Gram-negative bacterial infections [1]. The mechanism of action of ofloxacin in the body acts by inhibiting DNA gyrase (a type II topoisomerase and topoisomerase IV) which separate the replicated DNA, thereby inhibiting bacterial cell division [2]. Ofloxacin used for the treatment of urinary tract infections, infectious diarrhoea, infections of the urethra and cervix, pneumonia, cellulitis, chronic bronchitis, prostatitis, plague, multidrug resistant tuberculosis, bacterial infection of the eye and ear, otitis media when there is a hole in the ear drum, etc. $[1,3,4]$. The common side effects associate with the ofloxacin medication are headache, vomiting, diarrhea, tendon rupture, numbness, skin rash, seizures, psychosis, etc. [1]. Ofloxacin may increase the blood levels of other drugs such as theophylline, cyclosporine, warfarin, etc. by inhibiting the drug metabolizing enzymes. Ofloxacin showed to increase the anticoagulant, cardiotoxicity and arrhythmias effects, when co-administered with drugs such as of acenocoumarol, dihydroquinidine barbiturate, etc. $[4,5]$. It has a short biological half-life, and its bioavailability is strongly dependent on 
the physiological condition of the gastrointestinal tract (GIT). It is highly soluble in acidic media and precipitates in alkaline media thereby losing its solubility [4].

Since the physicochemical properties of a pharmaceutical compound play a crucial role in its dissolution, absorption, and bioavailability profile in the body [6]. Therefore, many research activities are carrying out throughout the world by the researchers for improving the physicochemical properties of the pharmaceuticals or nutraceuticals compounds. In this scenario, it was observed that The Trivedi Effect ${ }^{\circledR}$-Biofield Energy Healing Treatment has the significant impact on various properties such as particle size, surface area, and isotopic abundance ratios of pharmaceutical and nutraceutical compounds [7-9]. The Trivedi Effect $^{\circledR}$ is a natural and only scientifically proven phenomenon in which a person can harness this inherently intelligent energy and transmit it anywhere on the planet through the possible mediation of neutrinos [10]. "Biofield Energy" the electromagnetic energy field which exists surrounding the living beings, which can transmit the electromagnetic energy in the form of bio-photons, generated by the continuous movement of the electrically charged particles (ions, cells, etc.) inside the body. Biofield Energy Healing specialists have the ability to harness the energy from the environment or the "Universal Energy Field" and can transmit into any living and non-living object(s), this process is called Biofield Energy Healing Treatment [11-13]. Biofield based Energy therapies have been reported to with significant outcomes against various disease [14]. National Center of Complementary and Integrative Health (NCCIH) has recognized and accepted Biofield Energy Healing as a Complementary and Alternative Medicine (CAM) health care approach in addition to other therapies, medicines, and practices such as yoga, Qi Gong, Tai Chi, hypnotherapy, Reiki, etc. $[15,16]$ These therapies have been accepted by most of the U.S.A. population with several advantages [16]. The impact of The Trivedi Effect ${ }^{\circledR}$ Biofield Energy Healing Treatment had been proved scientifically with significant outcome in different fields, i.e., pharmaceuticals and nutraceuticals $[17,18]$, materials science $[19,20]$, agricultural science [21,22], microbiology [23,24], cancer research [25,26], etc. The Trivedi Effect ${ }^{\circledR}$-Biofield Energy Healing Treatment could be an economical approach and solution for the practical challenges faced by ofloxacin with respect to the physicochemical properties for designing better pharmaceuticals and nutraceutical formulations. The stable isotope ratio analysis has various applications in different scientific fields for understanding the isotope effects resulting from the variation of the isotopic composition of the molecule $[27,28]$. Isotope ratio analysis can be performed by using the conventional mass spectrometry (MS) techniques such as gas chromatographymass spectrometry (GC-MS) and liquid chromatography-mass spectrometry (LC-MS) in low micromolar concentration with sufficient precision [27,29]. Therefore, LC-MS and GC-MS were used in this study to characterize the structural properties and evaluate the isotopic abundance ratio analysis of $\mathrm{P}_{\mathrm{M}+1} / \mathrm{P}_{\mathrm{M}}\left({ }^{2} \mathrm{H} /{ }^{1} \mathrm{H}\right.$ or ${ }^{13} \mathrm{C} /{ }^{12} \mathrm{C}$ or ${ }^{17} \mathrm{O} /{ }^{16} \mathrm{O}$ or ${ }^{15} \mathrm{~N} /{ }^{14} \mathrm{~N}$ ) and $\mathrm{P}_{\mathrm{M}+2} / \mathrm{P}_{\mathrm{M}}\left({ }^{18} \mathrm{O} /{ }^{16} \mathrm{O}\right)$ in The Trivedi
Effect ${ }^{\circledR}$-Consciousness energy healing treated ofloxacin compared to the control sample.

\section{Materials and Methods}

\section{Chemicals and reagents}

Ofloxacin was purchased from Sigma Aldrich, USA. Other chemicals used during the experiments were of analytical grade available in India.

\section{Consciousness energy healing treatment strategies}

The test sample ofloxacin powder was divided into two parts. One part of ofloxacin powder sample was considered as a control sample (no Biofield Energy Treatment was provided). However, the other part of ofloxacin was treated with The Trivedi Effect ${ }^{\circledR}$ Consciousness energy healing treatment remotely under standard laboratory conditions for 3 minutes and known as The Trivedi Effect $^{\circledR}$ treated or Biofield Energy treated ofloxacin sample. The Biofield Energy treatment was provided through the healer's unique energy transmission process by the renowned Biofield Energy Healer, Alice Branton, USA, to the test sample. Further, the control sample was treated with "sham" healer for comparison purpose. The sham healer did not have any knowledge about the Biofield Energy treatment. After that, the Biofield Energy treated and untreated ofloxacin samples were kept in sealed conditions and characterized using LC-MS and GC-MS, analytical techniques.

\section{Characterization}

\section{Liquid chromatography-mass spectrometry (LC-MS) analysis and calculation of isotopic abundance ratio}

The LC-MS analysis of the control and Biofield Energy treated ofloxacin was carried out with the help of LC-MS/MS Thermo Fisher Scientific, the USA equipped with an iron trap detector connected with a triple-stage quadrupole mass spectrometer. The column used here was a reversed phase Thermo Scientific Synchronis $\mathrm{C}_{18}$ (Length-250mm XID-4.6mm X-5 micron), maintained at 25 ${ }^{\circ} \mathrm{C} .10 \mu \mathrm{L}$ of ofloxacin solution in methanol was injected, and the analyte was eluted using $0.1 \%$ formic acid in water (mobile phase A) and acetonitrile (mobile phase B) pumped at a constant flow rate of $0.6 \mathrm{~mL} / \mathrm{min}$. Chromatographic separation was achieved using gradient condition and the total run time was $10 \mathrm{~min}$. Peaks were monitored at $254 \mathrm{~nm}$ using the PDA detector. The mass spectrometric analysis was performed under +ve ESI mode. The total ion chromatogram, peak area $\%$ and mass spectrum of the individual peak which was appeared in LC along with the full scan (m/z 50-1500) were recorded. The total ion chromatogram and mass spectrum of the individual peak (appeared in LC-MS) were recorded. The natural abundance of each isotope $(\mathrm{C}, \mathrm{O}, \mathrm{H}$, and $\mathrm{N})$ can be predicted from the comparison of the height of the isotope peak with respect to the base peak. The values of the natural isotopic abundance of the common elements are obtained from the literature [28,30-32]. The LC-MS based isotopic abundance ratios 
$\left(\mathrm{P}_{\mathrm{M}+1} / \mathrm{P}_{\mathrm{M}}\right)$ for the control and Biofield Energy Treated ofloxacin was calculated.

Percentage (\%) change in isotopic abundance ratio= $\left[\left(\mathrm{IAR}_{\text {Treated }}-\right.\right.$ $\mathrm{IAR}_{\text {Control }}$ )/IAR $\left.\mathrm{IControl}_{\mathrm{X}} \mathrm{x} 100\right]$

Where $\mathrm{IAR}_{\text {Treated }}=$ isotopic abundance ratio in the treated sample and $\mathrm{IAR}_{\text {Control }}=$ isotopic abundance ratio in the control sample.

\section{Gas chromatography-mass spectrometry (GC-MS) analysis}

GC-MS of the control and Biofield Energy Treated sample of ofloxacin were analyzed with the help of Perkin Elmer Gas chromatograph equipped with a PE-5MS (30Mx250 microsx0.250 microns) capillary column and coupled to a single quadrupole mass detector was operated with electron impact (EI) ionization in positive mode. Oven temperature was programmed from $75^{\circ} \mathrm{C}$ (5 min hold) to $280{ }^{\circ} \mathrm{C} \mathrm{(14} \mathrm{min} \mathrm{hold)} \mathrm{@} 10{ }^{\circ} \mathrm{C} / \mathrm{min}$ (total run time $40 \mathrm{~min}$ ). The diluent for the sample preparation was acetonitrile in water. Mass spectra were scanned from m/z 40 to 400 . The identification of analyte was done by GC retention times and by a comparison of the mass spectra of samples. The GC-MS based isotopic abundance ratios $\left(\mathrm{P}_{\mathrm{M}+1} / \mathrm{P}_{\mathrm{M}}\right.$ and $\left.\mathrm{P}_{\mathrm{M}+2} / \mathrm{P}_{\mathrm{M}}\right)$ for the control and Biofield Energy Treated ofloxacin was calculated.

Percentage (\%) change in isotopic abundance ratio= $\left[\left(\mathrm{IAR}_{\text {Treated }}-\right.\right.$ $\left.\left.\left.\operatorname{IAR}_{\text {Control }}\right) / \operatorname{IAR}_{\text {Control }}\right) \times 100\right]$

Where $\mathrm{IAR}_{\text {Treated }}=$ isotopic abundance ratio in the treated sample and $\mathrm{IAR}_{\text {Control }}=$ isotopic abundance ratio in the control sample.

\section{Results and Discussion}

\section{Liquid chromatography-mass spectrometry (LC-MS)}

The LC chromatograms and mass spectra of both the samples of ofloxacin are shown in the (Figures 1 \& 2), respectively. The LC chromatograms of ofloxacin showed the single major chromatographic peak at the retention time $\left(R_{t}\right) 3.02$ minutes in both the case (Figure 1). This results indicated that the polarity of both the control and Biofield Energy Treated ofloxacin remained same. Ofloxacin was detected with the molecular mass peak $[\mathrm{M}+\mathrm{H}]^{+}$ at $\mathrm{m} / \mathrm{z} 362.0$ in the LC-MS spectrum in positive ion mode peak as per the literature [33]. The LC-ESI-MS spectra of both the samples of ofloxacin (Figure 2) at the retention time 3.02 minutes exhibited the mass of the protonated molecular ion peak at $\mathrm{m} / \mathrm{z} 362.17$ $[\mathrm{M}+\mathrm{H}]^{+}$(calculated for $\mathrm{C}_{18} \mathrm{H}_{21} \mathrm{FN}_{3} \mathrm{O}_{4}^{+}, 362.15$ ) in the control sample and Biofield Energy Treated sample, along with the fragment ion peaks near $\mathrm{m} / \mathrm{z} 318.25,261.08,143.58$, and 213.83 which were corresponded to the molecular formula $\mathrm{C}_{17} \mathrm{H}_{21} \mathrm{FN}_{3} \mathrm{O}_{2}{ }^{+}, \mathrm{C}_{13} \mathrm{H}_{9} \mathrm{FNO}_{4}{ }_{4}$, $\mathrm{C}_{12} \mathrm{H}_{10} \mathrm{~N}_{2} \mathrm{O}_{2}{ }^{2+}$, and $\mathrm{C}_{9} \mathrm{H}_{5} \mathrm{NO}^{2+}$, respectively in both the samples (Figure 3). The LC-ESI-MS spectra of both the control and Biofield Energy Treated ofloxacin showed the mass of the molecular ion peak $[\mathrm{M}+\mathrm{H}]^{+}$at $\mathrm{m} / \mathrm{z} 362.17$ (calculated for $\mathrm{C}_{18} \mathrm{H}_{21} \mathrm{FN}_{3} \mathrm{O}_{4}{ }^{+}, 362.15$ ) with relative intensity of $100 \%$.

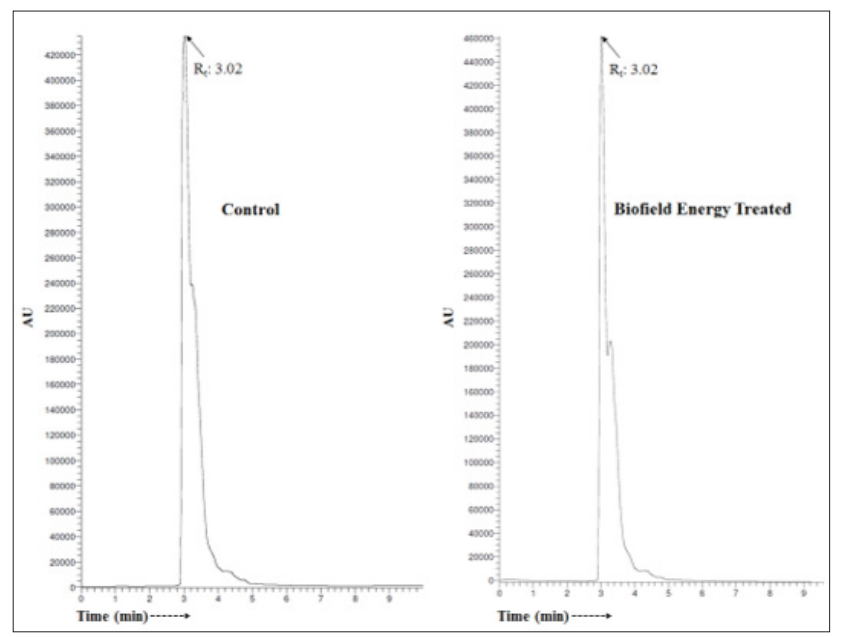

Figure 1: Liquid chromatograms of the control and biofield energy treated ofloxacin.

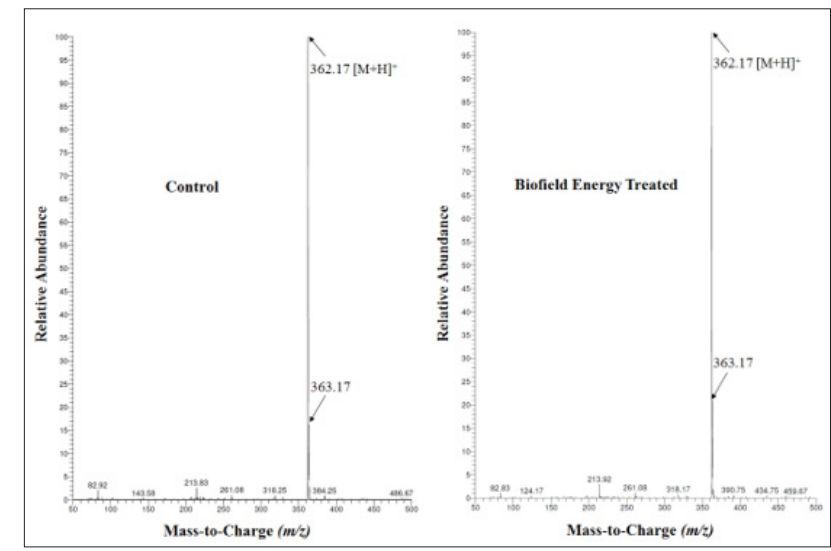

Figure 2: Mass spectra of the control and biofield energy treated ofloxacin at $\mathrm{rt} 3.02$ minutes.

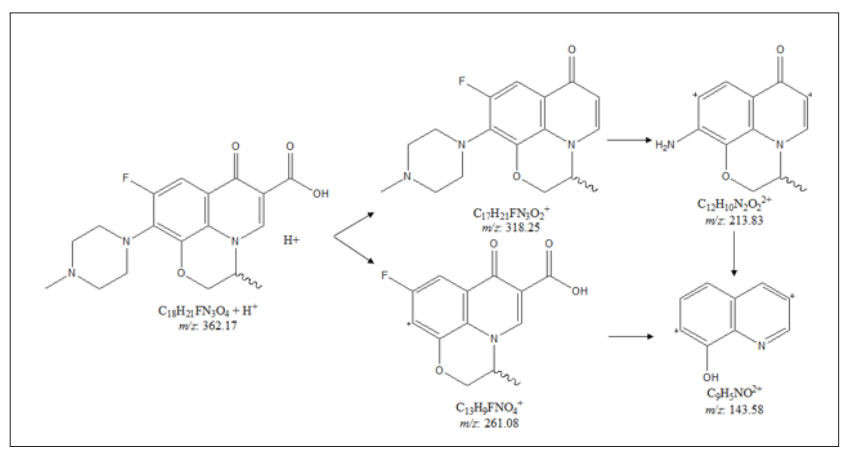

Figure 3: Proposed fragmentation pattern of ofloxacin.

The theoretical calculation of $\mathrm{P}_{\mathrm{M}+1}$ for ofloxacin was presented as below:

$\mathrm{P}\left({ }^{13} \mathrm{C}\right)=\left[(18 \times 1.1 \%) \times 100 \%\right.$ (the actual size of the $\mathrm{M}^{+}$ peak)] $/ 100 \%=18.8 \%$ 


$$
\begin{aligned}
& \mathrm{P}\left({ }^{2} \mathrm{H}\right)=[(21 \times 0.015 \%) \times 100 \%] / 100 \%=0.315 \% \\
& \mathrm{P}\left({ }^{15} \mathrm{~N}\right)=[(3 \mathrm{x} 0.4 \%) \times 100 \%] / 100 \%=1.2 \% \\
& \mathrm{P}\left({ }^{17} \mathrm{O}\right)=[(4 \mathrm{x} 0.04 \%) \times 100 \%] / 100 \%=0.16 \% \\
& \mathrm{P}_{\mathrm{M}+1,} \text { i.e. }{ }^{13} \mathrm{C},{ }^{2} \mathrm{H},{ }^{15} \mathrm{~N}, \text { and }{ }^{17} \mathrm{O} \text { contributions from }\left(\mathrm{C}_{18} \mathrm{H}_{21} \mathrm{FN}_{3} \mathrm{O}_{4}\right)^{+}
\end{aligned}
$$
to $\mathrm{m} / \mathrm{z} 363.17=20.28 \%$. From the above calculation, it has been found that ${ }^{13} \mathrm{C}$ and ${ }^{15} \mathrm{~N}$ have major contribution to $\mathrm{m} / \mathrm{z}$ 363.17. The calculated isotopic abundance is close to the experimental observed value (Table 1). The LC-MS based isotopic abundance ratio analysis of ofloxacin in control and Biofield Energy Treated samples were calculated for its molecular mass at $\mathrm{m} / \mathrm{z}$ 362.17. $\mathrm{P}_{\mathrm{M}}$ and $\mathrm{P}_{\mathrm{M}+1}$ for ofloxacin near $\mathrm{m} / \mathrm{z} 362.17$ and 363.17 , respectively of the control and Biofield Energy Treated samples, which were obtained from the observed relative peak intensities of $\left[\mathrm{M}^{+}\right]$and $\left[(\mathrm{M}+1)^{+}\right]$peaks, respectively in the ESI-MS spectra and are presented in (Table 1). The percentage change of the isotopic abundance ratio $\left(\mathrm{P}_{\mathrm{M}+1} / \mathrm{P}_{\mathrm{M}}\right)$ in the Biofield Energy Treated ofloxacin compared with the control sample are shown in Table 1 . The isotopic abundance ratio of $\mathrm{P}_{\mathrm{M}+1} / \mathrm{P}_{\mathrm{M}}$ in the Biofield Energy Treated ofloxacin was significantly increased by $28.65 \%$ compared with the control sample (Table 1 ). Hence, ${ }^{13} \mathrm{C},{ }^{2} \mathrm{H},{ }^{15} \mathrm{~N}$, and ${ }^{17} \mathrm{O}$ contributions from $\left(\mathrm{C}_{18} \mathrm{H}_{21} \mathrm{FN}_{3} \mathrm{O}_{4}\right)^{+}$to $\mathrm{m} / \mathrm{z}$ 363.17 in the Biofield Energy Treated sample were significantly increased compared with the control sample.

Table 1: LC-MS based isotopic abundance analysis results of ofloxacin in biofield energy treated sample compared to the control sample. Source: $\mathrm{P}_{\mathrm{M}}$ : The Relative peak intensity of the parent molecular ion $\left[\mathrm{M}^{+}\right] ; \mathrm{P}_{\mathrm{M}+1}$ : The Relative peak intensity of the isotopic molecular ion $\left[(\mathrm{M}+1)^{+}\right]$, M: Mass of the parent molecule.

\begin{tabular}{|c|c|c|}
\hline Parameter & Control Sample & $\begin{array}{c}\text { Biofield Energy } \\
\text { Treated Sample }\end{array}$ \\
\hline $\mathrm{P}_{\mathrm{M}}$ at $\mathrm{m} / \mathrm{z} 362.17(\%)$ & 100 & 100 \\
\hline $\mathrm{P}_{\mathrm{M}+1}$ at $\mathrm{m} / \mathrm{z} 363.17(\%)$ & 16.3 & 20.97 \\
\hline $\mathrm{P}_{\mathrm{M}+1} / \mathrm{P}_{\mathrm{M}}$ & 0.16 & 0.21 \\
\hline $\begin{array}{c}\% \text { Change of isotopic abundance } \\
\text { ratio }\left(\mathrm{P}_{\mathrm{M}+1} / \mathrm{P}_{\mathrm{M}} \text { ) with respect to }\right. \\
\text { the control sample }\end{array}$ & 28.65 \\
\hline
\end{tabular}

\section{Gas chromatography-mass spectrometry (GC-MS) anal- ysis}

The GC of the control and Biofield Energy Treated samples of ofloxacin showed the presence of several chromatographic peaks in the chromatograms (Figures $4 \& 5$ ). The retention times of the Biofield Energy Treated sample (23.08 minute) was close to those of the control sample (22.87 minutes). The peak area\% of Biofield Energy Treated ofloxacin (91.44\%) was increased by $0.7 \%$ compared to the control sample (90.81\%). Parent molecular ion peak of ofloxacin did not observe in any of the mass spectra of control and Biofield Energy Treated samples. Molecular fragment peak at $\mathrm{m} / \mathrm{z} 317$ (calculated for $\mathrm{C}_{17} \mathrm{H}_{21} \mathrm{FN}_{3} \mathrm{O}_{2}{ }^{+}, 317.15$ ) and $\mathrm{m} / \mathrm{z} 261$ (calculated for $\mathrm{C}_{12} \mathrm{H}_{10} \mathrm{~N}_{2} \mathrm{O}_{2}{ }^{2+}, 261.04$ ) of the control (Figure 4) and Biofield Energy Treated (Figure 5) ofloxacin were proposed from both the mass spectra. The mass peak intensities influence the isotopic abundance ratio, which was well supported by the LC-MS based isotopic abundance ratio analysis.

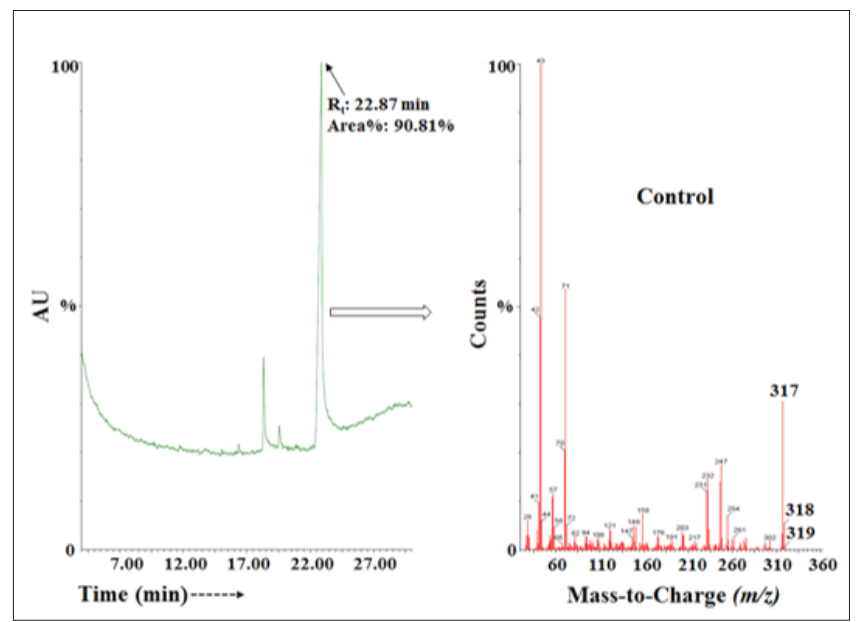

Figure 4: The GC-MS chromatogram and mass spectra of the control ofloxacin.

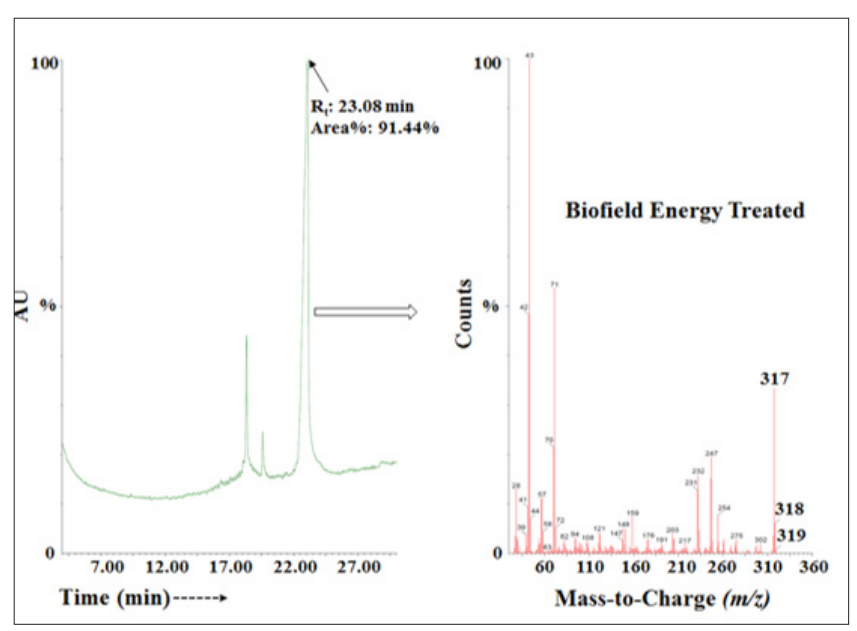

Figure 5: The GC-MS chromatogram and mass spectra of the biofield energy treated ofloxacin.

The GC-MS spectra of both the control and Biofield Energy Treated ofloxacin showed the mass of the fragmented molecular ion peak [M] $]^{+}$at $\mathrm{m} / \mathrm{z} 317$ (calculated for $\mathrm{C}_{17} \mathrm{H}_{21} \mathrm{FN}_{3} \mathrm{O}_{2}{ }^{+}, 317.15$ ). The theoretical calculation of $\mathrm{P}_{\mathrm{M}+1}$ for ofloxacin was presented as below:

$\mathrm{P}\left({ }^{13} \mathrm{C}\right)=\left[(17 \times 1.1 \%) \times 30.58 \%\right.$ (the actual size of the $\mathrm{M}^{+}$ peak)] $/ 100 \%=5.72 \%$

$$
\begin{aligned}
& \mathrm{P}\left({ }^{2} \mathrm{H}\right)=[(21 \times 0.015 \%) \times 30.58 \%] / 100 \%=0.1 \% \\
& \mathrm{P}\left({ }^{15} \mathrm{~N}\right)=[(3 \times 0.4 \%) \times 30.58 \%] / 100 \%=0.37 \% \\
& \mathrm{P}\left({ }^{17} \mathrm{O}\right)=[(2 \times 0.04 \%) \times 30.58 \%] / 100 \%=0.02 \% \\
& \mathrm{P}_{\mathrm{M}+1} \text { i.e. }{ }^{13} \mathrm{C},{ }^{2} \mathrm{H},{ }^{15} \mathrm{~N} \text {, and }{ }^{17} \mathrm{O} \text { contributions from }\left(\mathrm{C}_{17} \mathrm{H}_{21} \mathrm{FN}_{3} \mathrm{O}_{2}\right)^{+}
\end{aligned}
$$
to $\mathrm{m} / \mathrm{z} 318=6.21 \%$. From the above calculation, it has been found 
that ${ }^{13} \mathrm{C}$ and ${ }^{15} \mathrm{~N}$ have major contribution to $\mathrm{m} / \mathrm{z} 318$. Similarly, the theoretical calculation of $\mathrm{P}_{\mathrm{M}+2}$ for ofloxacin was presented as below:

$$
\mathrm{P}\left({ }^{18} \mathrm{O}\right)=[(2 \times 0.20 \%) \times 30.58 \%] / 100 \%=0.12 \%
$$

$\mathrm{P}_{\mathrm{M}+2 \text {, }}$ i.e., ${ }^{18} \mathrm{O}$ contributions from $\left(\mathrm{C}_{18} \mathrm{H}_{21} \mathrm{FN}_{3} \mathrm{O}_{4}\right)^{+}$to $\mathrm{m} / \mathrm{z}$ $319=0.12 \%$

From the above calculation, it has been found that ${ }^{18} \mathrm{O}$ have major contribution to $\mathrm{m} / \mathrm{z} 319$. The calculated isotopic abundance is close to the experimental observed value (Table 2).

Table 2: GC-MS based isotopic abundance analysis results of ofloxacin in control and biofield energy treated samples. Source: $\mathrm{P}_{\mathrm{M}}$ : The Relative peak intensity of the parent molecular ion $\left[\mathrm{M}^{+}\right] ; \mathrm{P}_{\mathrm{M}+1}$ : The Relative peak intensity of the isotopic molecular ion $\left[(\mathrm{M}+1)^{+}\right] ; \mathrm{P}_{\mathrm{M}+2}$ : The Relative peak intensity of the isotopic molecular ion $\left[(\mathrm{M}+2)^{+}\right], \mathrm{M}$ : Mass of the parent molecule.

\begin{tabular}{|c|c|c|}
\hline Parameter & Control Sample & $\begin{array}{c}\text { Biofield Energy } \\
\text { Treated Sample }\end{array}$ \\
\hline $\mathrm{P}_{\mathrm{M}}$ at $\mathrm{m} / \mathrm{z} 317(\%)$ & 30.58 & 33.33 \\
\hline $\mathrm{P}_{\mathrm{M}+1}$ at $\mathrm{m} / \mathrm{z} 318(\%)$ & 5.36 & 6.06 \\
\hline $\mathrm{P}_{\mathrm{M}+1} / \mathrm{P}_{\mathrm{M}}$ & 0.175 & 0.182 \\
\hline $\begin{array}{c}\text { \% Change of isotopic abun- } \\
\text { dance ratio }\left(\mathrm{P}_{\mathrm{M}+1} / \mathrm{P}_{\mathrm{M}}\right) \text { with } \\
\text { respect to the control sample }\end{array}$ & 0.78 & 3.73 \\
\hline $\mathrm{P}_{\mathrm{M}+1}$ at $\mathrm{m} / \mathrm{z} 319(\%)$ & 0.03 & 0.76 \\
\hline $\mathrm{P}_{\mathrm{M}+2} / \mathrm{P}_{\mathrm{M}}$ & & 0.02 \\
\hline $\begin{array}{c}\% \text { Change of isotopic abun- } \\
\text { dance ratio }\left(\mathrm{P}_{\mathrm{M}+2} / \mathrm{P}_{\mathrm{M}}\right) \text { with } \\
\text { respect to the control sample }\end{array}$ & & -10.6 \\
\hline
\end{tabular}

The GC-MS isotopic abundance ratio analysis of ofloxacin in the control and Biofield Energy Treated samples were calculated for its fragmented molecular mass at $\mathrm{m} / \mathrm{z} 317 . \mathrm{P}_{\mathrm{M}} \mathrm{P}_{\mathrm{M}+1}$, and $\mathrm{P}_{\mathrm{M}+2}$ for ofloxacin near $\mathrm{m} / \mathrm{z} 317,318$, and 319 , respectively of the control and Biofield Energy Treated samples, which were obtained from the observed relative peak intensities of $\left[\mathrm{M}^{+}\right],\left[(\mathrm{M}+1)^{+}\right]$, and $\left[(\mathrm{M}+2)^{+}\right]$ peaks, respectively in the ESI-MS spectra and are presented in (Table 2). The isotopic abundance ratio of $\mathrm{P}_{\mathrm{M}+1} / \mathrm{P}_{\mathrm{M}}$ in the Biofield Energy Treated ofloxacin was significantly increased by $3.73 \%$ compared with the control sample (Table 2). Hence, ${ }^{13} \mathrm{C},{ }^{2} \mathrm{H},{ }^{15} \mathrm{~N}$, and ${ }^{17} \mathrm{O}$ contributions from $\left(\mathrm{C}_{18} \mathrm{H}_{21} \mathrm{FN}_{3} \mathrm{O}_{4}\right)^{+}$to $\mathrm{m} / \mathrm{z} 318$ in the Biofield Energy Treated sample were significantly increased compared with the control sample. On the contrary, the isotopic abundance ratio of $\mathrm{P}_{\mathrm{M}+2} / \mathrm{P}_{\mathrm{M}}$ in the Biofield Energy Treated ofloxacin was decreased by $10.60 \%$ compared with the control sample (Table 2). Hence, ${ }^{18} \mathrm{O}$ contributions from $\left(\mathrm{C}_{18} \mathrm{H}_{21} \mathrm{FN}_{3} \mathrm{O}_{4}\right)^{+}$to $\mathrm{m} / \mathrm{z} 319$ in the Biofield Energy Treated sample were significantly decreased compared with the control sample.

Finally, LC-MS and GC-MS study confirmed the structure of ofloxacin. The LC-MS and GC-MS based isotopic abundance ratios of $\mathrm{P}_{\mathrm{M}+1} / \mathrm{P}_{\mathrm{M}}\left({ }^{2} \mathrm{H} /{ }^{1} \mathrm{H}\right.$ or ${ }^{13} \mathrm{C} /{ }^{12} \mathrm{C}$ or ${ }^{15} \mathrm{~N} /{ }^{14} \mathrm{~N}$ or $\left.{ }^{17} \mathrm{O} /{ }^{16} \mathrm{O}\right)$ and
$\mathrm{P}_{\mathrm{M}+2} / \mathrm{P}_{\mathrm{M}}\left({ }^{18} \mathrm{O} /{ }^{16} \mathrm{O}\right)$ in the Biofield Energy Treated ofloxacin were significantly altered compared to the control sample. As per modern physics, the neutrinos change identities which are only possible if the neutrinos possess mass and have the ability to interchange their phase from one phase to another internally. Therefore, the neutrinos have the ability to interact with protons and neutrons in the nucleus, which indicated a close relation between neutrino and the isotope formation [10,30,31]. The altered isotopic composition in molecular level of the Trivedi Effect ${ }^{\circledR}$-Consciousness Energy Healing Treated ofloxacin might be due to the alteration in neutron to proton ratio in the nucleus. It can be hypothesized that the changes in isotopic abundance could be due to changes in nuclei possibly through the interference of neutrino particles via The Trivedi Effect ${ }^{\circledR}$-Consciousness Energy Healing Treatment. The new form of ofloxacin (Biofield Energy Treated) would be better soluble and bioavailable compared to the control sample. It would be very useful to design better pharmaceutical formulations that might offer better therapeutic response against urinary tract infections, infectious diarrhoea, infections of the urethra and cervix (i.e., gonorrhea), pneumonia, cellulitis, chronic bronchitis, multidrug resistant tuberculosis, prostatitis, plague, bacterial infection of the eye and ear, otitis media when there is a hole in the ear drum, etc.

\section{Conclusion}

The experimental results revealed that The Trivedi Effect ${ }^{\circledR}$ Consciousness Energy Healing Treatment (Biofield Energy Healing Treatment) showed the significant impact on the isotopic abundance ratios, mass peak intensities, and peak area\% of ofloxacin. The LC-ESI-MS spectra of both the samples of ofloxacin at the retention time 3.02 minutes exhibited the mass of the protonated molecular ion peak at $\mathrm{m} / \mathrm{z} 362.17[\mathrm{M}+\mathrm{H}]^{+}$(calculated for $\mathrm{C}_{18} \mathrm{H}_{21} \mathrm{FN}_{3} \mathrm{O}_{4}^{+}, 362.15$ ). Similarly, the fragmented ion peaks were observed near $\mathrm{m} / \mathrm{z} 318.25,261.08,143.58$, and 213.83 which were corresponded to the molecular formula $\mathrm{C}_{17} \mathrm{H}_{21} \mathrm{FN}_{3} \mathrm{O}_{2}^{+}, \mathrm{C}_{13} \mathrm{H}_{9} \mathrm{FNO}_{4}^{+}$, $\mathrm{C}_{12} \mathrm{H}_{10} \mathrm{~N}_{2} \mathrm{O}_{2}{ }^{2+}$, and $\mathrm{C}_{9} \mathrm{H}_{5} \mathrm{NO}^{2+}$, respectively were proposed for both the samples. The LC-MS based isotopic abundance ratio of $\mathrm{P}_{\mathrm{M}+1} / \mathrm{P}_{\mathrm{M}}$ in the Biofield Energy Treated ofloxacin was significantly increased by $28.65 \%$ compared with the control sample. Thus, ${ }^{13} \mathrm{C},{ }^{2} \mathrm{H},{ }^{15} \mathrm{~N}$, and ${ }^{17} \mathrm{O}$ contributions from $\left(\mathrm{C}_{18} \mathrm{H}_{21} \mathrm{FN}_{3} \mathrm{O}_{4}\right)^{+}$to $\mathrm{m} / \mathrm{z} 363.17$ in the Biofield Energy Treated sample were significantly increased compared with the control sample. In the GC-MS the retention times of the Biofield Energy Treated sample (23.08 minutes) was found to be close to those of the control sample (22.87 minutes). The peak area\% of the Biofield Energy Treated ofloxacin (91.44\%) was increased by $0.7 \%$ compared to the control sample (90.81). Similarly, the GC-MS based isotopic abundance ratio of $\mathrm{P}_{\mathrm{M}+1} / \mathrm{P}_{\mathrm{M}}$ in the Biofield Energy Treated ofloxacin was significantly increased by $3.73 \%$ compared with the control sample. Hence, ${ }^{13} \mathrm{C},{ }^{2} \mathrm{H},{ }^{15} \mathrm{~N}$, and ${ }^{17} \mathrm{O}$ contributions from $\left(\mathrm{C}_{18} \mathrm{H}_{21} \mathrm{FN}_{3} \mathrm{O}_{4}\right)^{+}$to $\mathrm{m} / \mathrm{z} 318$ in the Biofield Energy Treated sample were significantly increased compared with the control sample. On the contrary, the isotopic abundance ratio of $\mathrm{P}_{\mathrm{M}+2} / \mathrm{P}_{\mathrm{M}}$ in the treated ofloxacin was decreased by $10.60 \%$ compared with the control 
sample. Therefore, ${ }^{18} \mathrm{O}$ contributions from $\left(\mathrm{C}_{18} \mathrm{H}_{21} \mathrm{FN}_{3} \mathrm{O}_{4}\right)^{+}$to m/z 319 in the Biofield Energy Treated sample were significantly decreased compared with the control sample. The LC-MS and GC-MS based isotopic abundance ratios of $\mathrm{P}_{\mathrm{M}+1} / \mathrm{P}_{\mathrm{M}}\left({ }^{2} \mathrm{H} /{ }^{1} \mathrm{H}\right.$ or ${ }^{13} \mathrm{C} /{ }^{12} \mathrm{C}$ or ${ }^{15} \mathrm{~N} /{ }^{14} \mathrm{~N}$ or $\left.{ }^{17} \mathrm{O} /{ }^{16} \mathrm{O}\right)$ and $\mathrm{P}_{\mathrm{M}+2} / \mathrm{P}_{\mathrm{M}}\left({ }^{18} \mathrm{O} /{ }^{16} \mathrm{O}\right)$ and peak area\% in the Biofield Energy Treated ofloxacin were significantly altered compared to the control sample. The new form of ofloxacin (Biofield Energy Treated) would be better soluble and bioavailable compared to the control sample. It would be very useful to design better pharmaceutical formulations that might offer better therapeutic response against urinary tract infections, infectious diarrhoea, infections of the urethra and cervix (i.e., gonorrhea), pneumonia, cellulitis, chronic bronchitis, multidrug resistant tuberculosis, prostatitis, plague, bacterial infection of the eye and ear, otitis media when there is a hole in the ear drum, etc.

\section{Acknowledgement}

The authors are grateful to Sophisticated Instrumentation Centre for Applied Research \& Testing (SICART) India, Trivedi Science, Trivedi Global, Inc., Trivedi Testimonials, and Trivedi Master Wellness for their assistance and support during this work.

\section{References}

1. Ofloxacin (2018) The American society of health-system pharmacists, USA.

2. Drlica K, Zhao X (1997) DNA gyrase, topoisomerase IV, and the 4-quinolones. Microbiol Mol Biol Rev 61(3): 377-392.

3. British national formulary (2015) British Medical Association. In: (69 ${ }^{\text {th }}$ edn), UK. pp. 1-1197.

4. https://en.wikipedia.org/wiki/Ofloxacin.

5. Van der Linden PD, Sturkenboom MC, Herings RM, Leufkens HM, Rowlands S, et al. (2003) Increased risk of achilles tendon rupture with quinolone antibacterial use, especially in elderly patients taking oral corticosteroids. Arch Intern Med 163(15): 1801-1807.

6. Chereson R (2009) Bioavailability, bioequivalence, and drug selection. In: Makoid CM, Vuchetich PJ, Banakar UV (Eds.), Basic pharmacokinetics ( $1^{\text {st }}$ edn.), Pharmaceutical Press, UK. p. 1-29.

7. Trivedi MK, Patil S, Shettigar H, Singh R, Jana S (2015) An impact of biofield treatment on spectroscopic characterization of pharmaceutical compounds. Mod Chem appl 3(3): 1-6.

8. Trivedi MK, Tallapragada RM, Branton A, Trivedi D, Nayak G, et al. (2015) Physicochemical characterization of biofield energy treated calcium carbonate powder. American Journal of Health Research 3(6): 368-375.

9. Trivedi MK, Branton A, Trivedi D, Nayak G, Panda P, et al. (2016) Gas chromatography-mass spectrometric analysis of isotopic abundance of ${ }^{13} \mathrm{C},{ }^{2} \mathrm{H}$, and ${ }^{18} \mathrm{O}$ in biofield energy treated p-tertiary butylphenol (PTBP). American Journal of Chemical Engineering 4(4): 78-86.

10. Trivedi MK, Mohan TRR (2016) Biofield energy signals, energy transmission and neutrinos. American Journal of Modern Physics 5(6): 172-176.

11. Rubik B (2002) The biofield hypothesis: Its biophysical basis and role in medicine. J Altern Complement Med 8(6): 703-717.

12. Nemeth L (2008) Energy and biofield therapies in practice. Beginnings 28(3): 4-5.
13. Rivera Ruiz M, Cajavilca C, Varon J (2008) Einthoven's string galvanometer: The first electrocardiograph. Tex Heart Inst J 35(2): 174178.

14. Rubik B, Muehsam D, Hammerschlag R, Jain S (2015) Biofield science and healing: History, terminology, and concepts. Glob Adv Health Med 4: 8-14.

15. Koithan M (2009) Introducing complementary and alternative therapies. J Nurse Pract 5(1): 18-20.

16. Barnes PM, Bloom B, Nahin RL (2008) Complementary and alternative medicine use among adults and children: United States, 2007. Natl Health Stat Report 12: 1-23.

17. Trivedi MK, Branton A, Trivedi D, Shettigar H, Bairwa K, et al. (2015) Fourier transform infrared and ultraviolet-visible spectroscopic characterization of biofield treated salicylic acid and sparfloxacin. Nat Prod Chem Res 3(5): 1-6.

18. Trivedi MK, Tallapragada RM, Branton A, Trivedi D, Nayak G, et al. (2015) Physicochemical characterization of biofield energy treated calcium carbonate powder. American Journal of Health Research 3(6): 368-375.

19. Trivedi MK, Mohan R, Branton A, Trivedi D, Nayak G, et al. (2015) Evaluation of atomic, physical, and thermal properties of bismuth oxide powder: An impact of biofield energy treatment. American Journal of Nano Research and Applications 3(6): 94-98.

20. Trivedi MK, Patil S, Tallapragada RM (2013) Effect of bio field treatment on the physical and thermal characteristics of vanadium pentoxide powders. J Material Sci Eng 11: 1-4.

21. Trivedi MK, Branton A, Trivedi D, Nayak G, Gangwar M, et al. (2015) Agronomic characteristics, growth analysis, and yield response of biofield treated mustard, cowpea, horse gram, and groundnuts. International Journal of Genetics and Genomics 3(6): 74-80.

22. Trivedi MK, Branton A, Trivedi D, Nayak G, Mondal SC, et al. (2015) Evaluation of plant growth, yield and yield attributes of biofield energy treated Mustard (Brassica juncea) and Chick Pea (Cicer Arietinum) Seeds. Agriculture, Forestry and Fisheries 4(6): 291-295.

23. Trivedi MK, Branton A, Trivedi D, Nayak G, Mondal SC, et al. (2015) Antibiogram, biochemical reactions and biotyping of biofield treated Providencia rettgeri. American Journal of Health Research 3(6): 344-351.

24. Trivedi MK, Patil S, Shettigar H, Gangwar M, Jana S (2015) An evaluation of biofield treatment on susceptibility pattern of multidrug resistant stenotrophomonas maltophilia: An emerging global opportunistic pathogen. Clin Microbiol 4(4): 1-5.

25. Trivedi MK, Patil S, Shettigar H, Mondal SC, Jana S (2015) The potential impact of biofield treatment on human brain tumor cells: A time-lapse video microscopy. J Integr Oncol 4(3): 1-5.

26. Trivedi MK, Patil S, Shettigar H, Gangwar M, Jana S (2015) In vitro evaluation of biofield treatment on cancer biomarkers involved in endometrial and prostate cancer cell lines. J Cancer Sci Ther 7(7): 253257.

27. Schellekens RC, Stellaard F, Woerdenbag HJ, Frijlink HW, Kosterink JG (2011) Applications of stable isotopes in clinical pharmacology. Br J Clin Pharmacol 72(6): 879-897

28. Weisel CP, Park S, Pyo H, Mohan K, Witz G (2003) Use of stable isotopically labeled benzene to evaluate environmental exposures. J Expo Anal Environ Epidemiol 13(5): 393-402.

29. Muccio Z, Jackson GP (2009) Isotope ratio mass spectrometry. Analyst 134(2): 213-222.

30. Rosman KJR, Taylor PDP (1998) Isotopic compositions of the elements 1997 (Technical Report). Pure Appl Chem 70(1): 217-235. 
31. Smith RM (2004) Understanding mass spectra: A basic approach. In: ( $2^{\text {nd }}$ edn.), Wiley, US. pp. 1-372.

32. Jürgen HG (2004) Mass spectrometry: A Textbook. In: (2 ${ }^{\text {nd }}$ edn.) Springer-Verlag Berlin Heidelberg, Europe. pp. 1-753.
33. Attimarad MV, Alnajjar AO (2013) A conventional HPLC-MS method for the simultaneous determination of ofloxacin and cefixime in plasma: Development and validation. J Basic Clin Pharm 4(2): 36-41.

For possible submissions Click below: 